\title{
EM HOMENAGEM E MEMÓRIA DA NOSSA QUERIDA MARIA DA GRAÇA
}

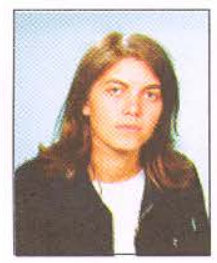

Homenagear a nossa querida Maria da Graça pela sua eterna memória é prestar-lhe a devida justiça do merecido reconhecimento da nobreza do seu generoso carácter e da existência cristã que praticou, com a sua naturalidade despretensiosa, mas inteligente.

Recordo a nossa querida Graça sempre disponível para auxiliar sem questionar retornos, sempre pronta a cumprir com dedicação e esmero, assertiva mas sem reacção negativa às agressões, antes oferecendo a outra face, abrindo o peito para enfrentar a luta quotidiana e a injustiça, corajosa e coerente na defesa das suas convicções, independentemente da popularidade da atitude. Recordo-a sempre leal e honesta recusando a intriga de bastidor, a mesquinhez e a adulação; lembro-a de previsão certeira, fino humor, apresentação apurada, visão larga e raciocínio rápido e perspicaz.

Testemunho o seu genuíno amor pelos seus Entes Queridos, pelo Próximo, pela sua Terra e pela Natureza. Testemunho a consistência do seu carácter, a simplicidade da sua pessoa, a força humanamente imparável do seu querer, apesar da sua extrema sensibilidade e também o seu inquestionável altruísmo que a levava a relegar-se, por inúmeras vezes, para segundo plano.

A nossa querida Graça não se lamentava dos seus problemas, das suas dores, das suas preocupações. Enfrentava-os sozinha, decidida, independente, com valentia, determinação, dignidade e de cabeça erguida. Era sempre assim. Nunca ninguém lhe ouvia um só queixume de dor, uma só palavra de desalento, um só murmúrio de revolta. Assim era, assim foi nos momentos mais difíceis: consciente, muito consciente, valente, muito valente; a sua preocupação era com o bem-estar dos outros, sempre com os outros e desistir não era com ela.

Era assim a nossa querida Gracinha.

Que Deus tenha piedade de si, a acolha, ilumine, guie e proteja na Sua infinita Paz, assim no Céu, como na Terra um dia aconteceu.

Que descanse na Paz do Senhor.

Saudade e dor. jvb.

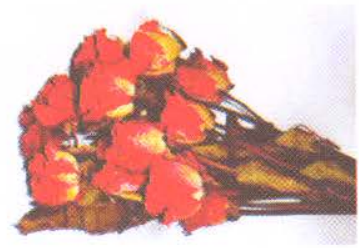

